\title{
Pendidikan Kesehatan tentang Remaja Sehat pada Adaptasi Kehidupan Baru di Kota Jambi
}

\author{
Mila Triana Sari ${ }^{1}$, Nel efni ${ }^{2}$ \\ ${ }^{1}$ Program Studi Profesi Ners STIKes Baiturrahim Jambi \\ ${ }^{2}$ Program Studi Ilmu Keperawatan Stikes Baiturrahim Jambi \\ Email: milatrianasari73@gmail.com
}

Submitted : 15/092020

Accepted: 29/09/2020

Published: 24/11/2010

\begin{abstract}
The adolescence wasa transition period from childhood to adulthood, which has many challenges from themselves or the environment, especially during the adaptation to a new life (New Normal). The Central Bureau of Statistics (2018) released the number of teenagers in Jambi province as $17.9 \%$ of the total population. If adolescents do not have the ability to face these challenges, it can have an impact on their personal health. The purpose of this activity is to increase adolescent knowledge regarding the adaptation of a new life. The activities carried out were in the form of health education using social media and power point slides. The result of this activity was an increase in adolescent knowledge about new life adaptations seen from the difference between the pre-test and post-test mean of 35.3\%. In conclusion, health education for adolescents is effective in increasing the knowledge and abilities of adolescents, especially regarding new life adaptations, therefore it is hoped that health workers will regularly provide health education and mentoring to adolescents, directly by following health protocols or using various social media
\end{abstract}

Keywords:adolescent, health education, new normal

\begin{abstract}
Abstrak
Remaja adalah suatu periode masa transisi dari masa anak-anak menuju dewasa, yang memiliki banyak tantangan dari diri sendiri ataupun lingkungan sekitar, terutama pada masa adaptasi kehidupan baru (New Normal). Biro Pusat Statistik (2018) merilis jumlah remaja di provinsi Jambi adalah $17,9 \%$ dari total jumlah penduduk. Apabila remaja tidak memiliki kemampuan untuk menghadapi berbagai tantangan tersebut, maka dapat berdampak pada kesehatan diri remaja. Tujuan dari kegiatan ini adalah agar terjadi peningkatan pengetahuan remaja berkaitan dengan adaptasi kehidupan baru. Adapun kegiatan yang dilakukan berupa pendidikan kesehatan menggunakan mediasosial dan slide power point. Hasil kegiatan ini terjadi peningkatan pengetahuan remaja tentang adaptasi hidup baru terlihat dari selisih rata-rata pre-test dan pos-test sebesar 35,3\%. Kesimpulan, pendidikan kesehatan kepada remaja efektif untuk meningkatkan pengetahuan dan kemampuan remaja,khususnya tentang adaptasi hidup baru, untuk itu diharapkan petugas kesehatan secara terjadwal memberikan pendidikan kesehatan dan pendampingan kepada remaja, secara langsung dengan mengikuti protokol kesehatan maupun dengan menggunakan berbagai media sosial.
\end{abstract}

Kata Kunci: adaptasi hidup baru, pendidikan kesehatan, remaja

\section{PENDAHULUAN}

Remaja adalah penduduk dengan rentang usia 10 hingga 18 tahun (Kemenkes RI, 2014). Badan Pusat Statistik (BPS) merilis jumlah remaja di Indonesia pada tahun 2018 yaitu sekitar 44. Penampilan fisik dan fungsi fisiologis. Selain itu secara psikologis adanya perubahan dalam asfek kognitif, emosi, sosial dan moral, hal ini merupakan periode kritis pertumbuhan dan perkembangan remaja. Remaja mengalami banyak tantangan baik dari diri sendiri ataupun lingkungan sekitar. Apabila remaja tidak memiliki kemampuan untuk menghadapi berbagai tantangan tersebut, maka dapat berdampak pada kesehatan diri remaja. Kompleksnya permasalahan kesehatan remaja, memerlukan penanganan 
yang komprehensif dan terintegrasi dari unsur terkait.New normal (adaptasi pada kehidupan baru) adalah fase dimana kebijakan pemerintah untuk bekerja, belajar, dan beribadah dari rumah pasca pandemi Covid-19, membutuhkan kesiapan khususnya bagi remaja, karena telah terjadi perubahan kebiasaan yang signifikan akibat kondisi ini. Sehingga, diperlukan kesiapan baik itu secara fisik, mental dan sosial untuk dapat beradaptasi kembali dengan perubahan-perubahan baru yang harus dijalani, khususnya pada remaja. Beberapa permasalahan yang muncul pada remaja antara lain pemahaman dan penghayatan terkait adaptasi hidup baru yang masih kurang, di ikuti dengan kesadaran yang masih rendah dan sikap yang kurang peduli, serta kejenuhan, adaptasi belajar dengan cara baru, menurunnya motivasi, tidak dapat bertemu teman dan sebagainya. Selain itu tidak sedikit remaja yang memanfaatkan kebijakan pemerintah untuk tetap dirumah sebagai kesempatan untuk bermalas-malasan dan tidak produktif sehingga memerlukan upaya untuk membangkitkan semangat belajar kembali dan perubahan-perubahan yang terjadi pada masa new normal ini. Intervensi yang dapat dilakukan sebagai salah satu upaya meningkatkan pengetahuan pada remaja untuk beradaptasi adalah memberikan pendidikan kesehatan pada remaja tentang perubahan-perubahan yang terjadi, dampak yang signifikan serta upaya yang dapat dilakukan oleh remaja agar mampu beradaptasi dalam tatanan hidup baru tersebut.

\section{TARGET DAN LUARAN}

Target dari kegiatan pengabdian ini adalah remaja yang berusia 10-18 tahun di wilayah kerja Puskesmas Simpang Kawat. Luarannya adalah meningkatkan pengetahuan remaja sehat meliputi perubahan yang dialami remaja pada masa pandemi, dampak yang terjadi, adaptasi kehidupan baru, langkah-langkah yang diperlukan dilakukan remaja pada adaptasi kehidupan baru.

\section{METODE PELAKSANAAN}

Kegiatan pengabdian kepada masyarakat ini dilakukan di wilayah kerja Puskesmas Simpang Kawat Kota Jambi, dengan metode memberikan pendidikan kesehatan terkait adaptasi remaja sehat pada tatanan hidup baru. Metode ini sesuai dengan tujuannya yaitu memberikan peningkatan pengetahuan sehingga remaja memiliki persepsi yang positif terkait beradaptasi pada tatanan hidup baru. Media yang digunakan dalam kegiatan ini adalah media visual yaitu slide Power Point (PPT). Media ini berguna untuk menstimulasi indra penglihatan pada saat dilangsungkannya pendidikan kesehatan. (Notoatmodjo, et.al, 2012).Kegiatan ini dilaksanakan pada bulan Juli - Agustus 2020 dengan jumlah peserta 25 orang remaja. Kegiatan pengabdian masyarakat ini dilaksanakan dengan beberapa tahapan yaitu 1) Tahapan persiapan, pada tahap ini tim mengidentifikasi permasalahan yang terjadi pada remaja diwilayah kerja Puskesmas Simpang Kawat sehingga dapat memutuskan tema untuk pendidikan kesehatan yang dilakukan. 2) Tahapan pelaksanaan kegiatan yaitu Pre-Test, Penyampaian materi pendidikan kesehatan tentang remaja sehat pada adaptasi tatanan hidup baru, diskusi, Post-Test, monitoring dan evaluasi dengan meminta feedback terhadap kegiatan yang dilakukan, serta tahapan terakhir adalah penulisan laporan. Kegiatan ini dilakukan menggunakan media sosial yaitu membuat grup WA (Whats $U P)$.Selain mitra dan pelaksana, kegiatan ini dibantu oleh beberapa orang mahasiswa Program SI Keperawatan Baiturrahim Jambi. 


\section{HASIL DAN PEMBAHASAN}

Hasil kegiatan pengabdian kepada masyarakat yang telah dilaksanakan terdapat 25 remaja yang berpartisipasi diwilayah kerja Puskesmas Simpang Kawat. Adapun rata-rata nilai pre-test sebesar $50,2 \%$ meningkat menjadi $85,5 \%$ pada saat post-test, (meningkat sebesar $35,3 \%$ ). Ini menunjukkan meskipun kegiatan pendidikan kesehatan dilakukan dengan WA, remaja tetap memperhatikan, sehingga terjadi peningkatan pengetahuan sebelum dan sesudah diberikan pendidikan kesehatan. Pendidikan kesehatan berjalan lancar karena remaja sudah melakukan kesepakatan di grup WA, meskipun tidak langsung bertatap muka. Evaluasi kegiatan yang sudah dilakukan termasuk dalam kategori baik. Beberapa tujuan yang diharapkan sudah tercapai. Remaja mengetahui tentang perubahan dan upaya yang dilakukan untuk beradaptasi dengan tatanan baru, Remaja juga aktif bertanya di WA, dan ada diantara peserta sendiri sudah mulai dapat menjelaskan jawaban kepada temannya yang bertanya, serta mengikuti kegiatan dari awal sampai akhir.

Pendidikan kesehatan diberikan untuk membantu individu, keluarga dan masyarakat untuk mencapai tingkat kesehatan yang optimal. Pendidikan kesehatan bertujuan untuk mengubah perilaku individu, keluarga, serta masyarakat dari prilaku tidak sehat menjadi prilakusehat(Widyanto, 2014).

Kegiatan pengabdian masyarakat melalui pendidikan kesehatan pada remaja diharapkan dapat meningkatkan pengetahuan dan pemahaman remaja terkait dengan adaptasi hidup baru. Ada beberapa hal yang dapat dipersiapkan remaja dalam menghadapi adaptasi hidup baru, meliputi persiapan mental, fisik dan sosial. Persiapan mental berkaitan dengan kesiapan diri secara psikologis agar dapat mencegah diri dari rasa stress karena beradaptasi dengan gaya hidup baru, hal ini dapat dilakukan dengan menyadari dan menerima realita bahwa perubahan sedang terjadi dan merespon perubahan tersebut dengan beradaptasi atau menyesuaikan diri. Selanjutnya adalah persiapan fisik berkaitan dengan kesiapan diri secara jasmani agar kondisi imunitas tubuh tetap terjaga dan terlindungi dari paparan virus, dengan mengkonsumsi makanan bergizi, terutama yang banyak mengandung vitamin c, olahraga, cukup istirahat dan menghindari zat adiktif antara lain rokok, serta menerapkan protokol kesehatan yaitu memakai masker, cuci tangan dan menjaga jarak (Larasati, 2020).
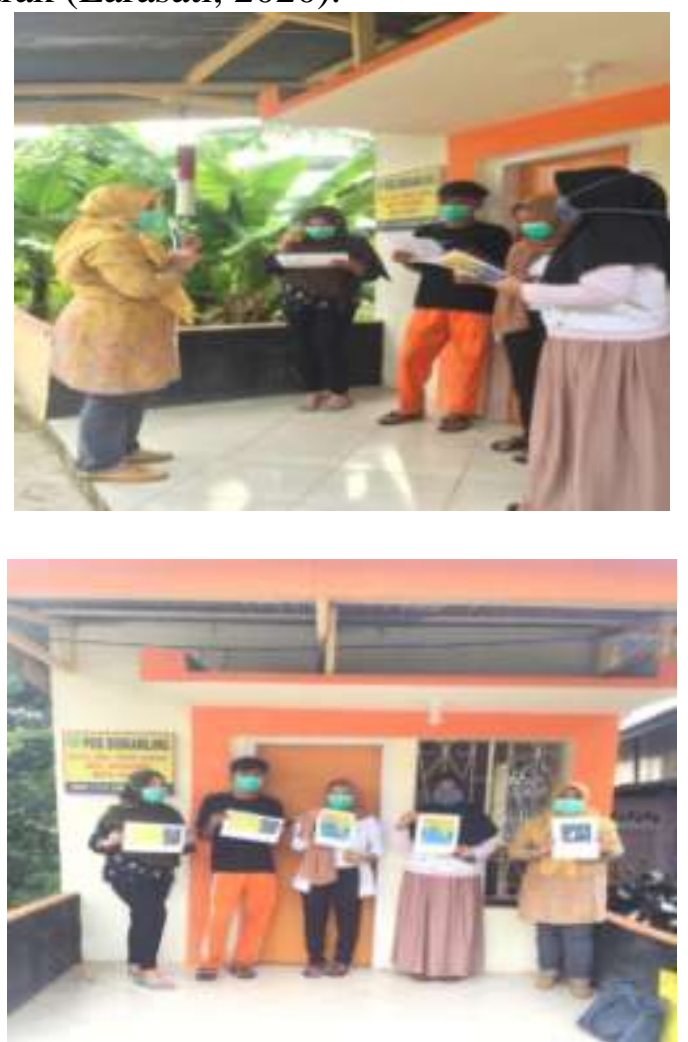

Gambar 1 dan 2, Kegiatan penyuluhan

Adanya peningkatan pengetahuan dan pemahaman remaja dalam beradaptasi pada tatanan hidup baru diharapkan remaja tetap dapat hidup sehat, produktif dan mampu beradaptasi yang pada akhirnya dapat meningkatkan derajat kesehatan remaja sehingga diperoleh generasi penerus bangsa yang berkualitas. 


\section{KESIMPULAN DAN SARAN \\ 1. Kesimpulan}

Kegiatan pengabdian masyarakat berupa pendidikan kesehatan dapat digunakan untuk meningkatkan pengetahuan remaja terkait adaptasi hidup baru pada masa pandemi covid 19 ini. Kegiatan pengabdian masyarakat berjalan lancar dan mendapat dukungan dari pihak mitra dan remaja.

\section{Saran}

Disarankan kepada petugas kesehatan, khususnya Unit Kesehatan remaja, agar hasil pengabdian masyarakat ini dapat menjadi bahan edukasi kesehatan bagi remaja dalam beradaptasi dalam tatanan hidup baru dimasa pandemi covid 19 ini, sehingga remaja tetap sehat dan produktif. Selain itu edukasi dapat dilakukan dengan berbagai cara khususnya pemanfaatan media sosial yang sudah sangat familiar di kalangan remaja.

\section{UCAPAN TERIMAKASIH}

Semua tim dan mitra pada kegiatan pengabdian ini mengucapkan terima kasih kepada:

1. Kepala Dinas Kesehatan Kota Jambi beserta jajarannya.

2. Kepala UPTD Puskesmas Simpang Kawat Kota Jambi beserta jajarannya.

3. Mitra dari Puskesmas Simpang Kawat terutama penanggung jawab dan pelaksana kegiatan konseling dan Unit Pos Yandu Remaja.

4. Ketua STIKes Baiturrahim Jambi beserta jajarannya.

5. Mahasiswa Program SI Keperawatan STIKes Baiturrahim Jambi.

6. Semua pihak yang membantu terlaksananya kegiatan ini.

\section{DAFTAR PUSTAKA}

Ahmad Kholid., Promosi Kesehatan dengan Pendekatan Teori Perilaku, Media dan aplikasinya., 2015. Jakarta; Rajawali Pres

Badan Pusat Statistik (BPS)., 2018.Statistik Indonesia 2018, Jakarta; BPS

Badan Pusat Statistik (BPS)., 2019. Statistik Indonesia., 2019, Jakarta; BPS

Dinas Kesehatan Provinsi Jambi., 2017. Profil kesehatan provinsi jambi. Jambi: Dinkes Provinsi Jambi.

Kementerian Kesehatan Republik Indonesia., 2014. Permenkes RI nomor 25 tahun 2014 tentang Upaya Kesehatan Anak Jakarta: Kemenkes, R.I.

Kementerian Kesehatan Republik Indonesia., 2014. Permenkes RI nomor 75 tahun 2014 tentang puskesmas. Jakarta: Kemenkes, R.I.

Larasati Ayu Pidari., 2020.Remaja Sehat di Era New Normal https://youtu.be/03rHZBYccwE

Notoatmodjo, S., 2012. Ilmu perilaku kesehatan kesehatan. Jakarta: Rineka Cipta.

Puskesmas Simpang Kawat., 2018. Profil Puskesmas Simpang Kawat Tahun 2017. Jambi: Puskesmas Simpang Kawat Jambi.

Widyanto Faisalaso Candra ., 2014. Keperawatan Komunitas dengan Pendekatan Praktis. Yogyakarta: Nuha Medika 